\title{
MUSIK SEBAGAI MEDIA BERBAGI IMAN
}

\section{Branckly Eigbert Picanussa}

\begin{abstract}
Music is a media not only used by Christians in worship but alsto to sharing faith. Christians should be used music to develop one of the christian spirituality that is serving and conveying people to Christ.
\end{abstract}

Keywords: Music, media, faith

\begin{abstract}
Abstrak
Musik merupakan salah satu media bukan hanya digunakan oleh orang-orang Kristen dalam peribadahan, tetapi juga untuk berbagi iman. Orang-orang Kristen sebaiknya menggunakan musik untuk mengembangkan salah satu bentuk dari spiritualitas kristiani, yakni melayani semua orang dan mengarahkannya kepada Kristus.
\end{abstract}

Kata Kunci: Musik, media, iman

\section{Pendahuluan}

Anne Ruck, dalam artikelnya "Komunitas Kristen di Indonesia Abad ke-

21: Bertumbuh dan Bersaksi?"1 mengajukan pertanyaan yang sangat menarik.

Siapakah dan bagaimanakah komunitas Kristen Indoensia abad ke21 ?Mampukah kita menunaikan tugas panggilan bersaksi di tanah air?Tentu saja tidak, kalau di dalam kekuatan manusiawi kita saja. ... Umat Kristen Indonesia menghadapi berbagai tangangan, terutama dalam hal diskriminasi dan keebasan beragama.Tetapi pada umumnya hubungan jemaat-jemaat lokal dengan masyarakat di sekitarnya baik.Isu-isu yang muncu hampir selalu karena ditiuptiupkan oleh pihak luar.Kesempatan bersaksi, melalui perkataan dan pelayanan kasih, sangat besar.Apakah kita memanfaatkan sebaik mungkin kesempatan yang ada? Apakah kita sadar akan panggilan gereja kita sebagai mitra Kristus dalam missio Dei, misi Tuhan dalam dunia, agar kita semua menjadi garam dan terang dan menjadi saluran berkat Tuhan kepada dunia? 
Sebagai orang-orang yang sungguh-sungguh beriman kepada Yesus Kristus, kita yakin bahwa oleh pertolongan dan Kasih Allah di dalam Yesus Kristus, komunitas Kristen Indonesia, bukan hanya abad ke-21 tetapi juga di abadabad selanjutnya akan tetap ada untuk menunaikan tugas menjadi garam dan terang dan mengembangkan spiritualitas kristiani serta bersaksi secara bertanggungjawab, efektif, dan efisien untuk menjadi berkat dan melayani sesama. Sehubungan dengan itu, tentu saja diperlukan berbagai media.Satu di antara berbagai media yang dapat digunakan adalah musik.

\section{Musik: Salah Satu bagian Integral dari Pelayanan Gereja}

Gereja tanpa musik bagaikan burung yang tidak memiliki kedua sayapnya. ${ }^{2}$ Di sepanjang sejarahnya, kekristenan diketahui sebagai suatu agama yang bernyanyi ... Kekristenan tidak akan pernah tanpa musik; sering dikatakan bahwa kekristenan tanpa musik adalah sesuatu yang tidak dapat dipikirkan. ${ }^{3}$ Jemaat-jemaat Kristen setiap saat dan setiap tempat membaca Alkitab, berdoa, dan bernyanyi, ${ }^{4}$ Melalui musik, orang-orang Kristen berdoa dan menyebarkan pesan-pesan Alkitab dan iman Kristen, ${ }^{5}$ dan melalui musik, para misionaris dari berbagai jaman telah menggunakannya untuk mengajar dan menyebarkan iman Kristen. ${ }^{6}$

Musik dalam kehidupan bergereja bukan hanya untuk peribadahan semata, melainkan juga untuk berbagi iman.Dari waktu ke waktu terlihat bahwa ekspresi bermusik dalam kehidupan orang-orang Kristen semakin meningkat.Pentingnya musik bagi kehidupan bergereja telah direfleksikan dalam beberapa pandangan, antara lain musikmerupakan bagian yang integral dari misi dan akan senantiasa menjadi bagian dari berbagai aktivitas misi yang dilakukan oleh gereja, ${ }^{7}$ musik merupakan salah satu agen pemuridan (discipling agent $)^{8}$ atau yang dalam bahasa Calvin M. Johansson disebut agen perubahan (change agent), ${ }^{9}$ dan bahwa musik yang memuridkan adalah musik gereja yang harus dikembangkan di masa-masa yang akan datang. ${ }^{10}$

Beberapa pernyataan tersebut memperlihatkan bahwa musik tidak akan pernah hilang dari kehidupan bergereja. Bahkan dapat dikatakan musik merupakan bagian integral dari keberadaan dan pengembangan gereja. Persoalannya adalah 
bagaimana setiap orang kristen dan gereja lebih memahami keberagaman fungsi musik dan menggunakannya untuk berbagi.

\section{Keberagaman Fungsi Musik}

Terdapat beberapa pandangan tentang fungsi musik.Dua diantaranya dikemukakan oleh Hunt dan Meriam.Dari kacamata bermisi, sebagaimana diinformasikan oleh Hunt, fungsi musik dapat dikelompokkan dalam 4 (empat) kategori. ${ }^{11}$

Pertama, fungsi alamiah, yang terdiri dari fungsi musik sebagai (1)media ekspresi spiritual; (2)media ekspresi kebudayaan (3)media ingatan; (4) media komunikasi; (5) media informasi; dan (6) media misi di berbagai tempat dan aktivitas kehidupan.

Kedua,fungsi sosialdalam ikatan psikologi dan spiritual, yang meliputi fungsi musik sebagai(1) media ekspresi semua kelompok, termasuk kaum perempuan; (2) media berekspresi yang terbuka bagi semua orang, termasuk di dalamnya orang yang malu dan takut mengekspresikan kepribadiannya; (3) media yang sangat bernilai dalam aktivitas misi kepada anak-anak; (4) media pemberitaan Injil kepada kelompok-kelompok yang memusuhi kekristenan; (5) daya tarik dan pendorong bagi kelompok; dan (6) media untuk memperteguh persekutuan umat Kristen.

Ketiga,fungsi musik yang secara khusus berhubungan dengan aktivitas bermisi. Sehubungan dengan itu dikemukakan beberapa hal, yakni (1) Musik berfungsi bagi efektivitas misi; (2) Musik berfungsi sebagai media yang bermanfaat untuk mengajar dan penyebaran konsep-konsep teologis; (3) Musik berfungsi sebagai media yang memiliki daya tarik yang khas; (4)Musik berfungsi untuk mengembangkan nilai-nilai kebangsaan; dan (5) musik dan nyanyian, di beberapa tempat misi berlangsung,berfungsi sebagai media pertunjukan dalam gaya lokal yang alamiah, fungsional, dan khas serta menjadi bagian dari seluruh kehidupan mereka.

Keempat, fungsi musik di dalam kehidupan Kristen. Tentang hal ini, Hunt memperlihatkan 8 (delapan) fungsi, yakni (1) media peribadahan; (2) media pengubah gaya hidup yang lama (penyembahan berhala) kepada gaya kehidupan 
yang baru (Kristen); (3) media pengembangan persekutuan kristiani; (4) media penguatan dalam suasana yang sulit (bnd. KPR 16:25). Dikemukakan pula bahwa terapi musik yang sekarang ini mulai dikembangkan sebenarnya sudah dikembangkan juga di dalam Perjanjian Lama (1 Sam 16:23); (5) media integrasi pesan dan orientasi kristiani dengan kehidupan sehari-hari; (6) media stabilisasi kehidupan orang-orang yang baru percaya; (7) media kesaksian kristiani; dan (8) media pengembangan bakat dan kepemimpinan kristiani.

Informasi Hunt tentang empat kategori fungsi musik dengan berbagai sub fungsinya yang beragam memberikan sumbangan pemikiran yang sangat penting bagi pengembangan musik dalam kehidupan orang-orang Kristen dan kehidupan bergereja. Menarik, bahwa apa yang dikemukakan Hunt, telah memperluas 10 fungsi utama musik yang pernah dikemukakan oleh A. P. Meriam, yakni fungsi “ekspresi, estetis, pertunjukan, komunikasi, simbolis, respon jasmaniah, penguatan, validasi institusi sosial dan keagamaan, kontinuitas dan stabilitas budaya, integrasi masyarakat." ${ }^{, 12}$ Sehubungan dengan fungsi musik yang dikemukakan oleh Meriam, karya Christian I. Tamaela dapat dijadikan sebagai contoh yang menarik. 


\section{PELA E}

Christian I. Tamaela
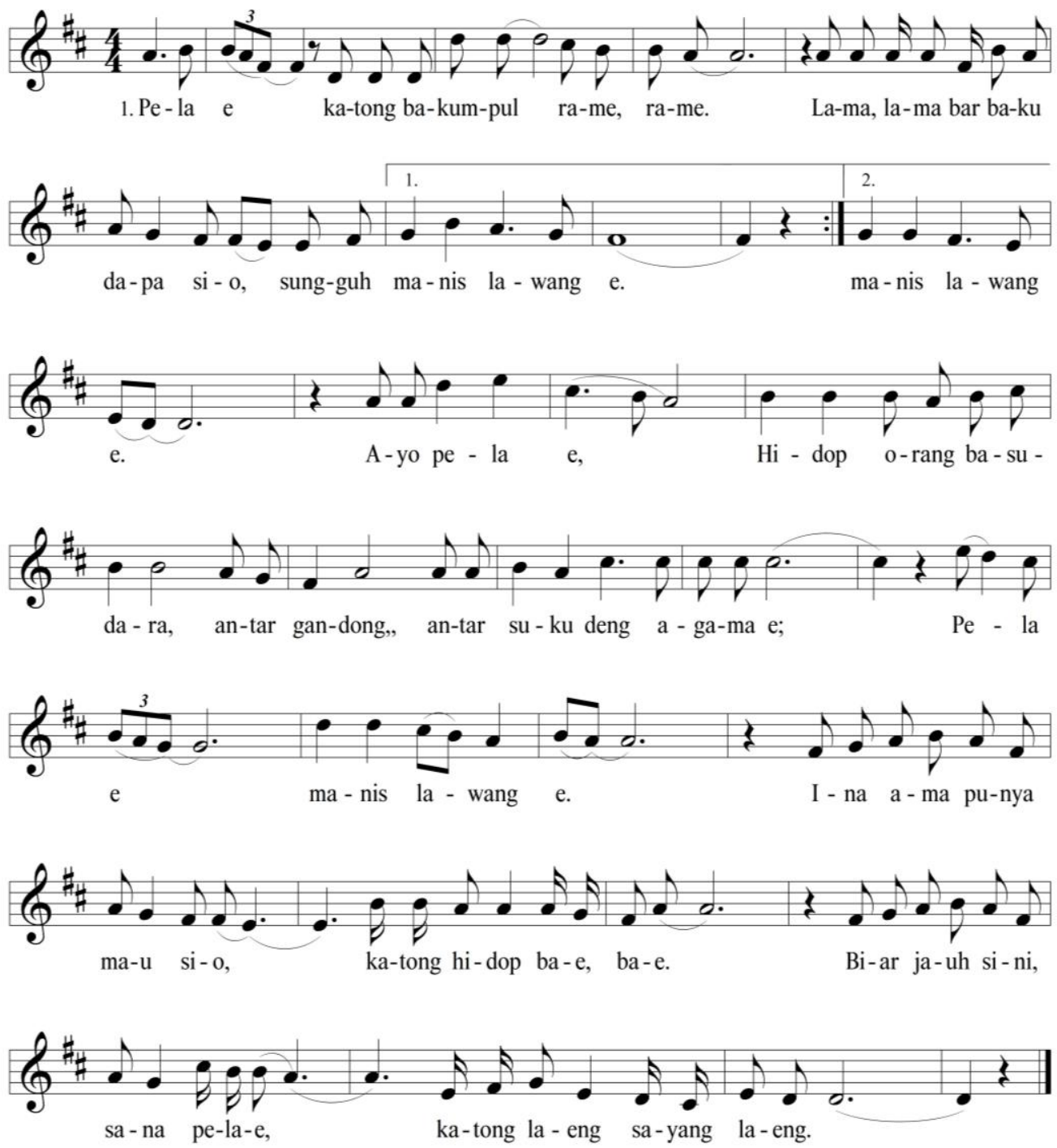

Melalui karyanya, Tamaela hendak mengekspresikan ide dan gagasan musikalnya secara estetis tentang sebuah budaya hidup orang-orang Maluku yang secara institusi sosial dikenal dengan nama pela - sebuah hidup yang baik antara orang-orang di Maluku antar gandong (bersaudara), suku, dan agama. Tamaela ingin mempertunjukan dan mengomunikasikan pela sebagai simbol hidup orang bersaudara di Maluku.Dengan menyanyikan nyanyian ini secara tidak langsung penyanyinya memberikan respon jasmaniahtentang indahnya hidup dalam persaudaraan.Melalui nyanyian ini, dapat juga dikatakan bahwa Tamaela hendak mempertegas keberadaan institusi sosial dan keagamaan untuk memelihara budaya 
tersebut, bahkan melestarikannya dan menjaga keberlangsungannya. Menarik bahwa nyanyian ini, sejak diciptakan pada tahun 1998, telah menjadi sebuah nyanyian yang dapat mengintegrasikan masyarakat yang ada di Maluku, masyarakat Maluku dalam berbagai kelompok gandong (persaudaraan), suku, dan agama.

Keberagaman fungsi musik, sebagaimana telah dikemukakan, memperlihatkan betapa musik memiliki peranan yang sangat penting dalam kehidupan manusia, termasuk orang-orang Kristen dan gereja. Oleh karena itu menggunakan musik sebagai media untuk berbagi iman Kristen dalam kehidupan, baik internal maupun eksternal, harus dilakukan secara bertanggungjawab.

\section{Iman ala James W. Fowler}

Sebagaimana telah dikemukakan, musik memiliki peranan yang sangat penting dalam kehidupan orang-orang Kristen dan gereja.Pentingnya peranan tersebut perlu disadari oleh setiap orang Kristen dan gereja untuk kemudian menggunakan musik secara bertanggung jawab sebagai media untuk berbagi iman Kristen dalam kehidupan, baik internal maupun eksternal.

Tidak dapat disangkal bahwa berbagi iman merupakan kewajiban dari setiap orang beragama.Akan tetapi, dalam kehidupan global dan sekuler saat ini, pertanyaan kritis yang dapat dimunculkan adalah konsep iman yang seperti apakah yang dapat dikembangkan dalam upaya berbagi?Untuk hal ini, konsep iman yang dikembangkan oleh James W. Fowler ${ }^{13}$ menjadi menarik untuk diperhatikan.

Iman, menurut Fowler, bukan hanya hal yang sangat personal melainkan juga universal. Iman memiliki kedudukan yang lebih tinggi dari agama dan juga kepercayaan. Iman merupakan hal yang penting bagi usaha dan keberadaan manusia di dalam berhubungan dengan yang transenden dan juga orang lain dalam berbagai praktek kehidupan keagamaan dan kepercayaan. ${ }^{14}$ Kata iman, menurut Fowler, memiliki arti yang lebih dari sekedar kata benda. Kata iman memiliki makna sebagai kata kerja atau berarti melakukan suatu aktivitas; faith "is in activity mode of being and commiting, a way of moving into and giving shape to our experience of life." Iman merupakan suatu kegiatan yang berhubungan dengan keberadaan, membuat komitmen, mengolah, dan memberikan makna kepada dan 
terhadap kehidupan yang dialami. Sebagai suatu aktivitas yang triadic shape, seseorang berada dalam hubungan dengan orang lain dan juga dengan satu (atau beberapa) kekuatan dan nilai yang hakiki. Hal yang tidak dapat dilepaskan oleh iman, menurut Fowler, adalah relationship. ${ }^{15}$

Lebih lanjut, Fowler juga mengemukakan faith as imagination. Menurutnya, pengetahuan kita sebenarnya berawal dari imajinasi dan bahwa imajinasi akan memberikan informasi dan dapat juga mengembangkan perasaan. Faith merupakan salah satu bentuk dari imaginasi manusia dalam memandang dan membentuk hubungannya dengan hal yang paling hakiki, baik alam nilai maupun kekuatan, yang kemudian dinyatakan dalam hubungan dengan orang lain. ${ }^{16}$

Beberapa hal tersebut dan juga urian lengkap dari buku yang ditulis oleh Fowler, Stages of Faith, memperlihatkan bahwa iman merupakan hubungan seseorang atau sekelompok orang dengan Allah untuk kemudian memberikan dan membagikan makna yang dilihat, dialami, dan dirasakan tersebut di dalam kehidupan bersesama dengan orang lain. Itu berarti iman (faith)sebagai aktivitas manusia yang personal tetapi juga berlangsung universal itu, sangat penting dan dialami oleh manusia di dalam seluruh keberadannya.

\section{Berbagi Iman melalui Musik ${ }^{17}$}

Diperhadapkan dengan keberadaan musik dalam kehidupan gereja dan orang-orang Kristen itu pada satu sisi, dan tugas untuk mewartakan iman pada sisi yang lain, sebuah pernyataan menarik pernah dikemuakan oleh T. W. Hunt: bukan hanya pada apakahkita akan menggunakan musik dalam misi kita, tetapi lebih daripada itu adalah bagaimana kita menggunakan musik secara efektif, efisien, bagi pengembangan spiritualitas kristiani untuk melayani sesama dan mengarahkannya kepada Kristus. ${ }^{18}$

Musik tidak hanya bermanfaat bagi orang-orang Kristen untuk aktivitas ekspresi iman dan aktivitas peribadahansaja, karena musik bila dimanfaatkan dengan baik dan dalam tuntunan Roh Kudus, akan melaksanakan peran didaktik yang penting (bnd. Kol 3:16), yakni sebagai media dan metode komunikasi yang efektif bukan hanya untuk aktivitas mengajar tentang Kristus dalam lingkup 
internal kristiani, tetapi juga untuk berbagi iman kristiani kepada lingkup eksternal.

Salah satu hal yang penting untuk diperhatikan dalam penggunaan musik (nyanyian) sebagai media komunikasi untuk berbagi iman krsitiani adalah kebijakan pengguna nyanyian untuk secara tepat memilih nyanyian dan mengartikan atau memaknaipesan yang terdapat di dalam nyanyian sehingga dapat dipahami dan direspon, baik secara positif atau negatif, oleh orang-orang yang menyanyikan atau mendengarkan nyanyian yang dinyanyikan.Nyanyian yang hendak digunakan untuk berbagi iman perlu dipersiapkan dengan baik.Nyanyian yang dinyanyikan hendaknya tertata dengan musik yang memberikan dukungan kepada nuansa dari nyanyian sehingga menarik untuk didengar dan diperhatikan.

Hal yang tidak boleh dilupakan dalam penggunaan musik untuk berbagi iman adalah pesan Alkitabiah, baik yang nonotatif maupun denotatif yang terkandung di dalam pesan yang dinyanyikan sehingga bermakna bagi orang-orang yang menyanyikan atau mendengarkannya. Selain itu, pemahaman tentang pengetahuan dan cara berpikir penerima serta berusaha mendalami keberadaan budaya dan lingkungan setempat perlu diperhatikan juga sehingga pesan iman kristiani menjadi efektif. Penggunaan musik sebagai media berbagi dalam dikembangkan dalam berbagai bentuk, antara lain pelayanan ibadah jemaat, paduan suara atau program-program paduan suara, dan konser musik khusus.

Berbagi iman kristiani melalui musik dapat dilakukan dengan tujuan untuk memberikan informasi pengantar yang diperdengarkan kepada penerima untuk mempersiapkannya mengambil keputusan yang tepat. Selain itu berbagi iman kristiani melalui musik dapat juga dilakukan secara langsung di sebuah tempat yang bertujuan menyajikan suatu krisis keputusan di dalam diri penerima dan di bawah pimpinan Roh Kudus, penerima untuk melihat realitas hidupnya dengan atau tanpa Kristus.

Sebagaimana telah dikemukakan pada bagian awal tulisan ini, bahwa oleh pertolongan dan Kasih Allah di dalam Yesus Kristus, komunitas Kristen Indonesia, bukan hanya abad ke-21 tetapi juga di abad-abad selanjutnya akan tetap ada untuk menunaikan tugas menjadi garam dan terang dan mengembangkan 
spiritualitas kristiani serta bersaksi secara bertanggungjawab, efektif, dan efisien untuk menjadi berkat dan melayani sesama.

Telah dikemukakan juga bahwa musik, dalam hal ini nyanyian, bila digunakan secara bertanggungjawab dapat menjadi salah satu alat untuk mengembangkan gereja dan spiritualitas kristani bukan hanya dalam peribadahan kristiani tetapi juga untuk melayani dan berbagi serta menjadi saluran berkat bagi kehidupan manusia di dunia ini, termasuk kehidupan umat manusia di Indonesia.

Bertemali beberapa pertanyaan yang dikemukakan oleh Ruck dalam salah satu artikelnya, sebagaimana telah dikemukakan di atas, dan konteks bermisi di Indonesia, serta penggunaan musik sebagai media berbagi, kombinasi pandangan Artanto Widi ${ }^{19}$ tentang menjadi Gereja Misioner dalam Konteks Indonesia dan penggunaan musik sebagai media berbagi menjadi hal yang tidak kalah menarik.

Misi merupakan tugas pengutusan yang diberikan Allah kepada orangorang Kristen untuk menghadirkan damai sejahtera Allah dalam kehidupan ini, baik secara internal maupun eksternal.Pelaksanaan misi yang selama ini cenderung dipahami sebagai kristenisasi sudah saatnya untuk diperbarui. Menghadirkan damai sejahtera Allah secara nyata di dalam kehidupan sehari-hari dan juga di dalam persekutuan dan pelayanan serta kesaksian merupakan tugas mendasar. Sehubungan dengan itu, maka diperlukan berbagai media, dan musik merupakan salah media yang efektif.

Karya Tamaela, sebagaimana telah dikemukakan, memperlihatkan bagaimana seorang musisi Kristen berbagi imannya. Iman yang dimaksudkan di sini adalah hubungan seseorang dengan Allah untuk kemudian memberikan dan membagikan makna yang dilihat, dialami, dan dirasakan tersebut di dalam kehidupan bersesama dengan orang lain.

Pela e, katong bakumpul rame-rame.

Lama-lama bar baku dapa sio sungguh manis lawang $e$

Pela e, katong bakumpul rame-rame.

Lama-lama bar baku dapat sio sungguh manis lawang $e$.

Ayo pela, hidup orang basudara antar gandong, antar suku deng agama e

Pela e, manis lawang e. Ina, Ama, pung mau sio katong hidup bae-bae

Biar jauh sini sana, pela e, katong laeng sayang laeng.

Tamaela, tentu saja, sangat menyadari bahwa hidup yang adalah Anugerah

Tuhan yang telah diberikan kepada para pendahulu kita sangatlah berharga dan 
harus dilestarikan.Oleh karena itu, berkumpul bersama dalam keberagaman kelompok persaudaraan, suku, dan agama adalah sebuah keindahan yang harus dipertahankan. Dalam praktekknya, nyanyian ini dapat dinyanyikan tanpa diiringi alat musik, tetapi dapat juga dinyanyikan dengan diiringi dengan alat-alat musik yang telah mentradisi di Maluku, misalnya tifa-totobuang, musik shawat, hawaian, gitar, ukulele, suling bambu, dan keyboard serta kombinasi dari beberapa alat musik tersebut.

Sungguh, tidak dapat dipungkiri bahwa melalui musik, misi berbagi iman yang bersifat internal maupun eksternal dapat dilaksanakan. Melalui musik, yang dikemas sedemikian rupa, proses berbagi sebagai bagian dari misi dapat dikembangkan. Musik, baik vokal maupun instrumental atau gabungan vokal dan instrumental, merupakan media berbagi iman yang perlu dimanfaatkan dengan baik oleh setiap orang Kristen dan juga gereja-gereja yang ada di Indonesia. Penggunaan musik sebagai media berbagi iman yang adalah bagian dari misi kristiani, tidak hanya terbatas pada bagaimana berbagai kehendak Allah disampaikan melalui musik, tetapi lebih daripada itu isi dari musik itu diwujudnyatakan oleh orang-orang Kristen.

Sebagai media berbagi iman, musik dapat dimanfaatkan sedemikian rupa oleh Gereja dan juga orang-orang Kristen untuk melibatkan diri dalam misi Allah dengan mewujudkan Misi, yang dalam pandangan Artanto Wididikelompokkan menjadi Misi Penciptaan, Misi Pembebasan, Misi Kehambaan, Misi Rekonsiliasi, dan Misi Kerajaan Allah:

- Dengan mempergunakan musik sebagai media berbagi di dalam misi, gereja terpanggil untuk terlibat dalam Misi Penciptaan yang menempatkan Gereja sebagai mitra Allah dan orang-orang lain yang menganut agama yang berbeda serta kelompok-kelompok gerakan lingkungan hidup untuk bersama-sama membangun masyarakat dan lingkungan hidup yang utuh serta melawan setiap usaha disintegrasi ciptaan Allah, termasuk di dalamnya disintegrasi kebudayaan. Dengan mempergunakan musik sebagai media berbagi iman di dalam pelaksanaan misi, gereja ikut serta mengembangkan pemikiran mengenai pembangunan yang berkelanjutan. 
- Dengan mempergunakan musik sebagai media berbagi iman, gereja terlibat dalam perjuangan pembebasan manusia dari belenggu ketidakadilan, penindasan dan pelanggaran hak asasi yang dipahami sebagai masalah bersama umat manusia. Keberpihakan gereja terhadap mereka yang miskin dan tertindas adalah sikap missioner yang adil karena mereka tidak memiliki kekuatan dan kekuasaan untuk memperjuangkan pembebasan mereka sendiri. Untuk itu, dengan mempergunakan musik sebagai media bermisi gereja perlu mengembangkan spiritualitas transformative yang berasal dari proses keterlibatan bersama mereka dan diakonia transformatif, di samping bentuk diakonia yang lain, dengan mendampingi dan melakukan proses penyadaran bersama mereka. Keterlibatan dalam Misi Pembebasan ini dapat diwujudkan oleh gereja dengan mempergunakan musik sebagai media berbagi yang bersifat profetis, baik pribadi maupun jemaat.

- Dengan mempergunakan musik sebagai media berbagi iman dalam bermisi, gereja menghayati dirinya sendiri sebagai hamba dalam komunitas yang saling melayani dan hidup dalam kesederhanaan sebagai wujud solidaritas Gereja terhadap keprihatinan sekitarnya. Selain itu, dengan menggunakan musik sebagai media berbagi iman dalam bermisi, gereja dengan rendah hati menghargai, dan melayani orang-orang beragama lain untuk memahamai kehendak Allah.

- Dengan mempergunakan musik sebagai media berbagi iman dalam bermisi, gereja terpanggil untuk melakukan penginjilan namun dengan pemahaman, strategi, dan tanggung jawab yang benar, serta konstekstual. Penginjilan dipahami sebagai undangan dalam perkataan dan perbuatan menuju pertobatan individu untuk mengalami rekonsiliasi dengan Allah. Rekonsiliasi ini mengandung dimensi sosial karena manusia dipanggil menjadi warga Kerajaan Allah yang aktif terlibat dalam menghadirkan cinta kasih, keadilan, perdamaian, dan integritas ciptaan. Di samping itu, rekonsiliasi dalam tubuh Gereja adalah bagian integral kesaksian gereja dalam pelaksanaan misi rekonsiliasi. 
- Dengan mempergunakan musik sebagai media berbagi iman dalam bermisi, gereja adalah hamba Kerajaan Allah yang tidak lagi hidup dalam egosentrisme tetapi mengarahkan seluruh keberadaan dan gerak misionernya untuk menghadirkan tanda-tanda Kerajaan Allah, kapan dan dimanapun gereja itu ada.

\section{Penutup}

Musik bukan hanya bermanfaat untuk aktivitas ekspresi iman dan aktivitas peribadahan, melainkan juga bermanfaat untuk berbagi iman.Pemanfaatan musik kristiani secara bertanggungjawab, tentu saja penting untuk dikembangkan. Tujuan utama dari penggunaan musik dalam kehidupan orang-orang Krsiten adalah untuk memuliakan Allah, bukan hanya digunakan untuk peribadahan di gereja atau pertemuan rutin atau harian orang-orang Kristen semata-mata, melainkan jugadalam tuntunan Roh Kudus - dapat dimanfaatkan sebagai media untuk berbagi iman kepada orang lain, menginformasikan tentang Kasih dan Damai Sejahtera Allah. Persoalannya adalah apakah pemanfaatan musik dalam kehidupan berbagi iman yang dilakukan oleh kita, orang-orang Krsiten, telah mengembangkan musik secara efektif dan efisien untuk mengembangkan salah satu bentuk dari spiritualitas kristiani, yakni melayani semua orang dan mengarahkannya kepada sebuah realitas: dengan atau tanpa Kristus?

\section{Catatan akhir:}

\footnotetext{
${ }^{1}$ Anne Ruck, "Komunitas Kristen di Indonesia Abad ke-21: Bertumbuh dan Bersaksi? Dalam John Ruck.et. al. Jemaat Misioner: Membawa kabar Baik dalam Masyarakat Majemuk abad XXI (Jakarta: Yayasan Komunikasi Bina Kasih), hlm. 199-121.

${ }^{2}$ Hendry van Dyke, "Music as an Aid to Faith" dalam Stanley Armstrong Hunter.editor. Music and Religion (New York: Abingdon Press, 1930), hlm. 27.

${ }^{3}$ T. W. Hunt. Music in Missions: Dicipling Throuhg Music (Nashville: Broadman Press, 1987), hlm. 11, 37.

${ }^{4}$ J. Gelineau,"Music and Singing in the Liturgy" dalam Cheslyn Jones, Geoffrey Wainwright, and Edward Yarnold. Editors. The Study of Liturgy (New York: Oxford University Press, 1978), hlm. 440.

${ }^{5}$ Bnd. T. W. Hunt. Ibid., 9; juga A. P. Merriam sebagaimana dikutip oleh Rudolf F. Radocy and J. David Boyle, Psychological Foundations of Musical Behavior (Springfield: Charles C. Thomas
} 
Publisher, 1979), hlm. 167, serta E. T. Gaston sebagaimana dikutip oleh Rudolf F. Radocy and J. David Boyle, Ibid., hlm. 168.

${ }^{6}$ J. Gelineau, Ibid., hlm. 442.

${ }^{7}$ T. W. Hunt.,Ibid.,hlm. 11.

${ }^{8}$ Ibid., hlm. 156.

${ }^{9}$ Calvin M. Johansson. Discipling Music Ministry: Twenty-first Century Directions (Massachusetts: Hendrickson Publishers Inc., 1992), hlm. 165.

${ }^{10}$ Ibid., hlm. vi.

${ }^{11}$ Ibid.

${ }^{12}$ A. P. Meriam sebagaimana dikutip oleh Rudolf F. Radocy and J. David Boyle, Psychological Foundations of Musical Behavior (Springfield: Charles C. Thomas Publisher, 1979), hlm. 164167.

${ }^{13}$ James W. Fowler.Stages of Faith: The Psychology of Human Development and the Quest for Meaning (San Francisco: Harper \& Row Publishers, 1981)

${ }^{14}$ Ibid.,James W. Fowler, hlm. 9-15.

${ }^{15}$ Ibid.,hlm. 16-23.

${ }^{16}$ Ibid.,hlm. 24-31.

${ }^{17}$ Bertemali dengan pemanfaatan musik untuk "berbagi iman", penulis mencoba untuk membaca dan mengadaptasikan pandangan yang dikemukakan oleh Hunt ${ }^{17}$ dari "kacamata berbagi iman melalui musik".

${ }^{18}$ T. W. Hunt.,Ibid.,hlm. 31-33.

${ }^{19}$ Artanto Widi, Menjadi Gereja Misioner dalam Konteks Indonesia, BPK Gunung Mulia dan Kanisius, Jakarta-Yogyakarta, 1997.

\section{DAFTAR PUSTAKA}

Ruck, John. et. al. Jemaat Misioner: Membawa kabar Baik dalam Masyarakat Majemuk abad XXI (Jakarta: Yayasan Komunikasi Bina Kasih).

Van Dyke, Hendry.,1930. "Music as an Aid to Faith” dalam Stanley Armstrong Hunter.editor. Music and Religion, New York: Abingdon Press.

Hunt.,T. W. 1987. Music in Missions: Dicipling Throuhg Music, Nashville: Broadman Press.

Cheslyn Jones, Geoffrey Wainwright, and Edward Yarnold. Editors. 1978.The Study of Liturgy, New York: Oxford University Press.

Radocy, Rudolf F. and J. David Boyle, 1979.Psychological Foundations of Musical Behavior, Springfield: Charles C. Thomas Publisher.

Johansson.Calvin M.,1992. Discipling Music Ministry: Twenty-first Century Directions, Massachusetts: Hendrickson Publishers Inc.

Fowler, James W. Fowler.,1981.Stages of Faith: The Psychology of Human Development and the Quest for Meaning, San Francisco: Harper \& Row Publishers. 
Widi, Artanto.,1997. Menjadi Gereja Misioner dalam Konteks Indonesia, Jakarta: BPK Gunung Mulia dan Kanisius: Yogyakarta. 